\title{
Post Demonetization and GST: Indian Economy Losing Its Steam - Myth or Reality
}

\author{
Effulgence \\ Vol. 16 (Special Issue) \\ January - June, 2018 \\ Rukmini Devi Institute of Advanced Studies \\ E-mail : effulgence@rdias.ac.in, Website :www.rdias.ac.in \\ http://effulgence.rdias.ac.in/user/default.aspx \\ https://dx.doi.org/10.33601/effulgence.rdias/v16/iSpl1/2018/article0.2
}

\section{Dr. Himanshu Rastogi ${ }^{1}$}

\begin{abstract}
India has moved ahead from being considered as unsafe investment destination and once been labeled as a crawling economy with indecisive political will and numerous hurdles. After the introduction of Liberalization, Privatization and Globalization policy in 1991 Indian economy started bearing fruits of progress and the growth engine started steaming to bring India among the front runners in terms of sustained economic growth. Today India is one of the important constituent of BRICS nations and is redefining economic growth with potential of becoming third economic power (China, US and India) by 2030 (Price Waterhouse Coopers (PwC) Report 2015). India is today is the seventh largest economy in the world at 2.2 trillion USD in terms of nominal GDP and third in terms of PPP. The economy is expected to expand to 5 trillion USD by 2025 as per Morgan Stanley Report 2017. The other positives in India's favor are stable and committed government at the center, one of the youngest nations having 65 percentage of population below the age of 35 year. When economy was marching with strength there were certain issues which needed immediate attention relating to increasing base of black money, tackling corruption, and restructuring indirect tax system. The Narendra Modi led government in order to combat the black money announced demonetization of Rs.500 and Rs.2000 currency notes on 8th November 2016 making them to lose legal status of tender money from midnight of same day. Apart from this the Government introduced tax reforms by introducing GST with effect from 1st July 2017 replacing multiple cascading taxes levied by the central and state governments. The impact of these two tough decisions was that the economic growth fell to three years low at 5.7 percent in the April-June Quarter of 2017, even below China. There started hue and cry over the tough decision taken by the government. In this background paper tries to analyze whether the Indian Economy has really lost its steam because of these two major decisions or it is just a short term fluctuation and not a long trend arising out of cleansing the system and will march with glory in times to come and place our country on the world map economically more progressive. The paper is based on secondary source of data gathered from various newspapers, reports, journals and websites. The limitation of the paper depends upon the quality, reliability and accuracy of data obtained from various data sources; however efforts have been made to make use of only authentic source of information to the maximum possible extent.
\end{abstract}

Keywords: Economic Growth, Black Money, Demonetization, GST.

1. Amity Business School, Amity University Uttar Pradesh - Lucknow Campus, drhrastogi@gmail.com 


\section{INTRODUCTION}

Tndia is a country having economy of dual character. It leads on many fronts and leads in terms of technological development, emergence of strong middle income community, changing lifestyle, growth of youths and so on, but at the same time country faces huge challenges in terms of huge unorganized sector, poor banking habits, unemployment problem, huge volume of unaccounted and black money in the economy, vast spread of corruption to mention a few. With all these odds India has emerged as an important constituent of BRICS nations and been frontrunners in terms of economic growth for last decade or so with potential to emerge as one of the important pillars of top three economic powers of future. To achieve the goal of future carrier of world economic growth it was necessary to cleanse the economy, as almost 25 percent of GDP was constituted by black economy of which around 10 percent was cash economy based on black money, and streamline the tax base. With these two broad objectives the Government of India took two bold steps in terms of demonetization of high value currency notes and introduction of GST within a year.

\section{LITERATURE REVIEW}

Shakir Shaik; S.A.Sameera; Sk.C. Firoz (2015) in their paper titled "Does Goods and Services Tax (GST) Leads to Indian Economic Development?" examined Goods and Services Tax (GST) as a comprehensive tax levy on manufacture, sale and consumption of goods and services at a national level. One of the biggest taxation reforms in India the (GST) is all set to integrate State economies and boost overall growth. Currently, companies and businesses pay lot of indirect taxes such as VAT, service tax, sales tax, entertainment tax, octroi and luxury tax. Once GST is implemented, all these taxes would cease to exist. There would be only one tax, that too at the national level, monitored by the central government. GST is also different in the way it is levied - at the final point of consumption and not at the manufacturing stage. At present, separate tax rates are applied to goods and services. Under GST, there would be only one tax rate for both goods and services. GST is expected to create a business friendly environment, as price levels and hence inflation rates would come down overtime as a uniform tax rate is applied. It will also improve government's fiscal health as the tax collection system would become more transparent, making tax evasion difficult. The paper tried to study the concept of goods and service tax and its impact on Indian economy. It also focused on the advantages and challenges of GST in Indian scenario.

Shefali Dani (2016) in her paper titled "A Research Paper on an Impact of Goods and Service Tax (GST) on Indian Economy" stated that, there is a huge hue and cry against its implementation. It would be interesting to understand why this proposed GST regime may hamper the growth and development of the country.

Sandeep Kaur (2016) published in his paper titled "Demonetization and Its Impacts in India", elaborated the effect of demonetization on black money and corruption, funding of terrorism and smuggling activities, real estate funding, promotion of digital payments, attack on fake currency, control on inflation to name a few.

Vedashree Mali (2016) in her paper titled " Demonetization: A step towards modified India", focused on the reasons for demonetization decision and its impact on various sectors of the economy with special reference to its impact on Micro Businesses, E-Wallet businesses, online retail stores and others.

Suresh P. Singh and Memory Dube (2011) in their article "BRICS and the World Order: A Beginners Guide" proved that the BRIC acronym, which stands for Brazil, Russia, India and China, originated in a Goldman Sachs paper - Building Better Global Economic BRICs - as part of an economic modelling exercise to forecast global economic trends over the 
next half-century. The main finding was that the BRIC countries collectively would play an increasingly important role in the global economy.

\section{OBJECTIVES}

1. To understand the concept of demonetization and GST

2. To understand the problems that come across with the implementation of demonetization and GST

\section{DEMONETIZATION}

Demonetization simply means change of national currency from old to new, implying that the old unit of currency is replaced with new currency. The basic purpose of demonetization act is to control inflation, black money, corruption and to control terrorism activities faced by the country concerned.

To India demonetization is not new, the currency has been demonetized two times earlier as well. The first was on 12th January 1946 when notes of denominations Rs.1000 and 10000 rupees were withdrawn from circulation and new currency notes of Rs.1000. Rs.5000 and Rs.10000 were introduced in 1954. On 16th January 1978 Janata Party coalition government again demonetized banknotes of denominations Rs.1000, Rs.5000 and Rs.10000 to curb counterfeit currency and black money. In both these demonetizations the Indian economy was not so vibrant, because very few people have access to these high denomination notes, and was not popular to common man.

However the present demonetization announced on 8th November, 2016 had widespread repercussions because Rs.500 and Rs.1000 notes being very widely circulated denominations.

With the current demonetization the entire scenario related to currency in circulation changed drastically as the economy was left only with 14 percent legal tender money thus squeezing the cash available in the hands of people to be utilized for transactions.

Table 1: Status of Currency in Circulation - Post Demonetization

\begin{tabular}{|c|c|c|c|c|}
\hline $\begin{array}{c}\text { Money in Circulation } \\
\left(8^{\text {th }} \text { November 2016) }\right.\end{array}$ & $\begin{array}{c}17.77 \text { lakh } \\
\text { crore }\end{array}$ & & & \\
\hline $\begin{array}{c}\text { Money Becoming Invalid (86\% } \\
\text { of Legal Money) }\end{array}$ & 14.18 lakh crore & $\begin{array}{c}7.85 \text { lakh crore } \\
\text { (Rs 500/- Note) }\end{array}$ & (Rs 1000/- Note) \\
\hline $\begin{array}{c}\text { Currency Back with Banks (97\% } \\
\text { of Invalid Currency) }\end{array}$ & 13.75 lakh crore & & \\
\hline $\begin{array}{c}\text { Govt Expectations (Failed) } \\
\text { JD Accounts Deposit before } \\
\text { Demonetization }\end{array}$ & 45636 & & $\begin{array}{c}\text { 3 lakh crore will not } \\
\text { come back to banks }\end{array}$ & \\
\hline $\begin{array}{c}\text { JD Accounts Deposit after } \\
\text { Demonetization (January 2017) }\end{array}$ & $\begin{array}{c}87000 \\
\text { Crore }\end{array}$ & & & \\
\hline
\end{tabular}

Source: Compiled from various government websites 


\section{ANALYSIS OF TABLE}

The above table reveals that total money in circulation as on 8th November 2016 prior to announcement of demonetization was to the tune of Rs.17.77 lakh crore. The decision of demonetizing Rs.500 and Rs.1000 currency notes resulted in withdrawing the legal status of Rs.14.18 lakh crore consisting of 7.85 lakh crore of Rs.500 denomination currency notes and Rs.6.33 lakh currency notes of Rs.1000 denominations. As such only 14 percent currency notes of small denominations were left in the economic system for performing monetary transactions in cash terms. The act of demonetization resulted in flushing out of undeclared and hidden black money back into the banking channels and as on 28th December 2016 almost 97 percent i.e. 13.75 lakh crore of demonetized currency had been deposited with banks.

As regards amount deposited with Jan Dhan Accounts is concerned there were deposits to the value of Rs. 45636 crore in 19.88 crore active accounts on the date of announcement of demonetization which swelled to Rs.87000 crore as on January 2017. This shows that the money has been brought back to the white stream.

\section{Two Main Objectives of Demonetization}

\section{Crackdown on Black Money}

The prime objective of demonetization was to destroy the black money which was running the parallel economy and resulted in huge loss to the government in the form of evasion of tax revenue. This decision was made curb the black money chain by making hoarders of black money to suffer loss when the unaccounted cash becomes a paper piece. The government was of the view that by withdrawing high value notes around 4 lakh crore worth of cash i.e. almost 12 percent held in black money and fake currency will become worthless. This could not happen as by December 2016 almost all the currency which lost its legal status due to demonetization has returned back to banking system. Nearly $97 \%$ of the outlawed Rs.500 and Rs.1000 notes has been deposited with banks as on December 30, according to Bloomberg news service. Thus the entire exercise seems to be futile which gives an impression that either there existed, no black money in the form of cash in the system and most of it has been converted in real estate or gold. The other remedy that the tax evaisors might have put all their black money deposited back in banks through several bank accounts or through benami accounts of relatives and poor people having jan dhan accounts. These ways adopted by the black money holders are very much exposed and government is talking tough on these issues through conduct of raids and sealing of benami accounts. However the positive is that this demonetization exercise has resulted in generation of huge deposits with banks. Now, with government acting tough and imposing limits on cash transactions, with possibilities to further squeeze cash transactions in future time to come, more recorded transactions can be promoted which will certainly put effective brakes on generation on black money.

\section{A Move Towards Cashless Economy}

One of the prime objective of demonetization was to make people less dependent on cash transactions and rely more and more on digital way of making payment so that the transactions gets recorded in bank books and black money can be checked. With demonetization squeezing almost major chunk of money in circulation from the economy people were willingly or unwillingly made to take the route of electronic mode of payment. Many those who till date were relying only on cash transactions and were feared of electronic portals gradually started enjoying this new mode of making payments as well. The result of demonetization has been that within 30 days of note ban digital payments have showed an increase of almost 300 percent. As per government data the number of daily transactions through ewallet services such as Oxigen, Paytm and MobiKwik has shot up from 17 lakh, recorded on 
November 8 when demonetisation was announced, to 63 lakh as on December 7, 2016 showing a growth of $271 \%$. In terms of value, the surge has been $267 \%$, from Rs.52 crore daily to Rs.191 crore now.

Transactions through RuPay Cards (e-commerce and point-of-sale) were up $316 \%$ at 16 lakh daily as against 3.85 lakh on November 8, while in terms of value the growth has been $503 \%$ at Rs. 236 crore from Rs.39 crore.

\section{GOODS AND SERVICE TAX (GST)}

Goods and Service Tax is an indirect tax reform which aims to remove tax barriers between states and create a single market. The Goods and Services Tax which is being implemented from 1st July, 2017 is proposed to be a unified tax for the entire nation. The intended objective of GST 2017 is to replace a lot of other indirect and direct taxes like the VAT, service tax, luxury tax etc. GST is aimed at being comprehensive with most of the goods and services included in the GST bill but alcohol and petrol exempted.

\section{MAIN OBJECTIVES OF GST}

1. To eliminate the cascading effects of taxes i.e. tax on tax, on production \& distribution costs of goods and services across the country.

2. Uniformity of tax rates across the country by subsuming all indirect taxes at the centre and state levels i.e.one nation-one tax.

3. To reduce tax evasion and corruption.

4. Increasing Tax-to-GDP ratio and revenue surplus.

\section{DEMONETIZATION AND GST IMPLEMENTED WITHOUT PROPER PLANNING}

It is argues that both demonetization and implementation of GST were introduced without proper planning and homework on the part of the Government in haste which resulted to huge inconvenience and financial scarcity to the public and small businessmen. The following points were highlighted in support of improper planning by the policy makers.

- People have to leave work and stand in queues for banking transaction, for exchanging only 4000 rupees at one chance. Most of the time even standing in ques for full day they could not succeed to change their high denomination either they could not make into the bank or because banks felt short of funds. For salaried people they have salary in hand but still were poor, this was the situation of the country.

- ATM's had long ques even when they weren't working. Disappointment happened when they got to know that the ATM couldn't give them the new 2000 rupee note because of its size. Out of 4-5 ATM's in every area only one could serve the local citizen. Neither the bank account help them nor the cash in hand.

- Too frequent changes regarding withdrawal limit over the counter and through ATMs and subsequently changing limit regarding exchange of old currency notes further created chaos among the public. For instance on November 8th 2016 government allowed Rs.4000 old currency noted to be exchanged at banks counter which was increased to Rs.4500 on November 13 but the limit was slashed and curtailed down to Rs.2000 only on November 17.

- There have been frequent changes in the GST rates ever since its rollout on 1st July 2017. Since then GST rates have been revised at least three times which has created a confusing state in the minds of traders and they are finding it very difficult to cope with this new tax regime.

- Traders and business class are also finding it unmanageable how to keep accounts of several GST rates as for the same class of commodity there are two slabs for instance the cinema ticket costing up to Rs.100 a GST rate of 18 percent and for tickets above Rs.100 GST at the rate of 28 percent was applied. This type of dual rate for same products and services is putting a lot of pressure on trade people.

- The approach of the government that it will take 
care of the rates and is ready to revise them as they are communicated regarding the difficulties being experienced by traders and industrialists in the proper flow and growth of business is not at all appreciable as it reflects that the Government had not done its homework properly before implementing the GST system.

\section{POST DEMONETIZATION AND GST IMPLEMENTATION: INDIA ECONOMIC GROWTH- DATA SHEET \& ANALYSIS}

Table-2: GDP Quarterly Growth Rate Pre \& Post Demonetization and GST Rollout

\begin{tabular}{|l|c|}
\hline \multicolumn{1}{|c|}{ Quarter } & GDP Growth Rate \\
\hline July 2016 - September 2016 & 7.3 percent \\
\hline October 2016 - December 2016 & 7.0 percent \\
\hline January 2107 - March 2017 & 6.1 percent \\
\hline April 2017 - June 2017 & 5.7 percent \\
\hline July 2017 - September 2017 & $7.0-7.5$ percent (P) \\
\hline
\end{tabular}

Source: Compiled from various government websites

\section{ANALYSIS:}

The table reveals that the GDP growth rate started losing its steam even before the announcement of Demonetization of high worth currency notes announced on 8th November 2016 and rollout of GST on 1st July 2017. However after the implementation of these two bold decisions the pace of fall in GDP growth rate became sharp and fell to a 3 year low of 5.7 percent in the April-June 2017 quarter. This gave critics to raise their voices against the government and they started pointing out that the Government has fooled and cheated the public and in fact they termed their demonetization and GST polices as "Organized Loot."

The point to be noted is that whenever any hard policy decision is implemented to cleanse the economy and the system it will always have adverse impact on the economy in the short run but will definitely yield positive and fruitful results in long run. Thus one should give cooling time to the economy to settle down and absorb jitters of tough decisions.

Things started changing from September onwards and economy started showing the signs of revival much before the expected time period signaling that the country has taken the two major decisions in the right spirit and are ready to adapt the new way of doing business in the changed tax regime and are accept the digitization mode of payment for purchases rather than completely depending on cash dealings. Citizens of India have started given acceptance to more transparent system.

The improvements suggest that the aftershocks of demonetization and the rollout of the goods and services tax (GST) are wearing off.

- Steady and robust growth was visible for a while in sales of passenger vehicles and tractors, while early signs of growth recovery are visible in August in two-wheeler sales and in rail freight.

- One of the bright spots in the economy is a 10.29 per cent jump in exports in August to USD 23.8 billion from USD 21.5 billion in the same month a year earlier.

- Manufacturing PMI rose to 51.2 in August, indicating an expansion from 47.9 in July. A reading above 50 indicates expansion, and below that a contraction.

- International rating agency Moody's Investors Service raised India's sovereign rating for the first time since 2004 to Baa2 from Baa3 and changed its rating outlook to stable from positive, saying that at the Baa2 level risks to India's credit profile were broadly balanced. This 
reflects that the tough decisions of the Government have been appreciated at international levels as well.

- Moody's forecast GDP growth of 6.7 percent for the fiscal year ended March 2018, with a pick up to 7.5 percent in the following year and "similarly robust" levels from 2019 onward.

- India, which had the mantle of world's fastest growing major economy, slipped below China in terms of growth which reported a growth rate of 6.9 percent for the quarter ended June 2017 against India 5.7 percent for the same period. With recovery signs again emerging in Indian economy it is expected that India's GDP growth rate will overtake China's in the next financial year as per the Interim Economic Outlook report released by Organization for Economic Cooperation and Development (OECD).The OECD report maintains that the economy will regain its momentum and achieve a growth of 7.2 percent in 2018, overtaking China that will see a growth rate of 6.6 percent during the same period.

\section{CONCLUSION}

The above analysis leads to conclude that there is an old saying that hit the iron when it is hot. Based on this saying the Government of India planned and decided to implement to major decisions related to Demonetization of high denomination notes and introduction of GST as the economy was growing at $7+$ percent growth rate and was in a situation to absorb the short term shocks arising out of such strict economic decisions. The economy showed positive response and after experiencing the short term jitters is now again on the growth path and soon it will start steaming in full strength, regain its strong economic position on the world economic forum. To say that demonetization has failed is not correct as though almost 97 percent has come back to banks but, the point to be noted is that now once the black money after been recorded on bank accounts is now liable to be taxable on any financial transactions taking place. Similarly the trade dealing with the introduction of GST has to be accountable and tax evasion will be curtailed. As a closing remark it is submitted that the two decisions will be remembered as wise decisions on the part of government in making honest efforts to cleanse the economy and promote higher economic growth and transparency.

\section{REFERENCES}

1) Ali Syed Haider Zaidi , Xin-Yu Wang, Iqbal Pervaiz , Ahmad Sardar , Rehman Saif UR and Sajid Muhammad (2017), "The Dilemma of Demonetization and Its Impact on Indian Economy," International Journal of Advanced Research, Vol. 5, Issue 4, PP. 652-667.

2) Dash A. (2017), "A Study on Socio Economic Effect of Demonetization In India," International Journal of Management and Applied Science, Vol. 3, Issue 3, PP. 13-15.

3) Kaur Sandeep (2016), "Demonetization and its Impact in India," International Journal of Research, Vol. 3, Issue 17, PP. 1151-1154.

4) Mali Vedashree, (2016), “Demonetization: A Step towards Modified India," International Journal of Commerce and Management Research, Vol. 2, Issue 12, PP. 35-36.

5) Sahu Ranjana (2017), "Demonetisation and Its Impact on Indian Economy," Journal Of Information, Knowledge and Research in Business Management and Administration, Vol. 4, Issue 2, PP. 125-129.

6) Shah Ayash Yousuf (2017), "Impact of Demonetization on Rural India," International Journal of Scientific and Research Publications, Vol. 7, Issue 3, PP. 220-223.

7) Shaik Shakir, Sameera S.A., Firoz Sk.C. (2015), "Does Goods and Services Tax (GST) Leads to Indian Economic Development?" IOSR Journal of Business and Management, Vol. 17, Issue 12, Ver. III, PP. 1-5.

8) Shefali Dani. (2016), “An Impact of Goods and Service Tax (GST) on Indian Economy, "Business and Economics," an open access journal.

9) Veerakumar K (2017), “A Study on People Impact on Demonetization," International Journal of Interdisciplinary Research in Arts and 
Humanities, Vol. 2, Issue 1, PP. 9-12.

10) h t t p : / / w w w . b u s i n e s s standard.com/article/economy-policy/on-june18-gst-council-to-discuss-revision-of-rates-onmore-items-117061500595_1.html

11)http://www.news18.com/news/business/indias -gdp-growth-hits-3-year-low-of-5-7-as-gstdemonetisation-take-a-toll-1506177.html 